\title{
TEXTBOOKS FOR ART EDUCATION: FUNCTIONS AND LIMITATIONS
}

\section{James Loomis}

Although there are many titles available to the field of art education, which can and do contribute to several classroom settings, the books considered in this paper are those which are suited to the art teacher preparation process. Three books are employed as examples in demonstrating a structure for examining theories in art education books. This structure is predicated partially on knowledge of theories of art, the psychology of individual participation in the arts and the sociology of art. Each of these domains has shaped the content of teacher certification programs through its inclusion in the books which have been instrumental to the development of art education since its inception.

The more that knowledge about art education theory is acquired, the easier it becomes to view it as a conglomerate concept. It is conglomerate in that it contains a wide range of independent component parts, the components drawn from several disciplines, each component adding shades of meaning to the whole concept. Theoretical aspects of sociology, psychology and aesthetics meld to form a single art education theory. Art education theory is also subject to temporal influences, e.g., existing political, economic, social or moral values and conditions.

Theories, because of their background of component parts, have roots, origins which predicate their current meaning. Tracing the lineage of a theory is much like any geneological study, it begins with the present and step-by-step delves into the past.

I have chosen to begin this theoretical geneology with an examination of Preparation for Art, the second edition, by June King McFee (1970). The theory domains to be examined in this paper, art, sociology and psycnology, serve as the basis for Preparation for Art.

In Preparation for Art, the second edition, McFee (1970) provides a definition of art education which embodies the three theoretical domains examined by this paper.

Art education is defined as an educational process to help diverse children and young people to (1) develop understanding of the language of art as it functions in society, (2) understand the range of art in the man-made environment, (3) develop the behaviors to produce creatively and respond to art, and (4) critically evaluate art through aesthetic judgment. The teacher's role in art education includes understanding this process, with emphasis on individual differences in readiness for art through the psychological and social study of human behavior in art, and curriculum development that will help diverse children achieve these abilities and understandings. (p. 21)

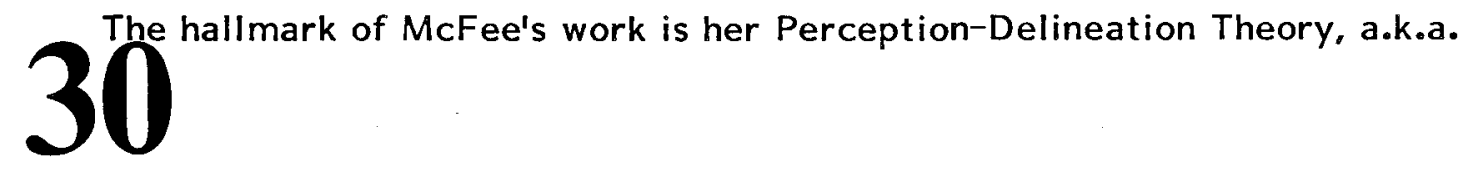


P-D. By her own admission, P-D is an eclectic theory of art, with its focus on child-centered and on curriculum-centered art education. McFee's description of $P-D$ is as follows:

The perception-delineation theory (P-D) presented in this book is eclectic. Many pertinent studies have contributed to its formation. Some of its roots are in Gestalt or "field" psychology. The field (like the field in the physical sciences) means a whole situation, the parts of which are dynamically interdependent (the development of one influences the development of the others). (p. 17)

Here we see an art theory which has an established foundation in psychological theory and a link to the sociological theory domain. The psychological roots of McFee's work, have been based largely on the work of Jerome Bruner and H. A. Witkin, both Gestaltists. Inquiry in the area of social behavior conducted by Wallach and Kagan, and the work of Guilford and Getzels in the area of cognition, contributed to McFee's study. To put this into terms of a geneology, it is primarily the work of these psychologists, and definitely the Gestaltist school of thought, which has "parented" McFee's psychological foundation for the P-D theory. It must be noted that McFee has drawn from and/or cited numerous other psychologists than those named above, but those who have been mentioned can be considered of primary influence.

McFee leans on the work of Thomas Munro, whose study of art history theories from an anthropological base, yielded patterns within cultures. Anthropologists Gerbands and Herskovits have made, for the most part, the complement of McFee's base in that area.

It is McFee's consideration of many areas, with roots in aesthetics and the social and behavioral sciences, which makes Preparation for Art a solid contribution to art education. In it, McFee (1970) makes a testimony to the contributions made to art education by Viktor Lowenfeld, and uses this testimony as a preface to her own work. Lowenfeld's contributions in Creative and Mental Growth, first published in 1947, have been important in the growth of art education. Of particular note, is Lowenfeld's theory of visual and haptical orientations in art. In examining the background of art education theories for their roots in aesthetics, the social sciences and the behavioral sciences, Creative and Mental Growth, by Viktor Lowenfeld and W. Lambert Brittain (1970). Creative and Mental Growth provides this look at the field of art education:

However, art has been traditionally interpreted as relating mainly to aesthetics, and this concept has in some cases limited the opportunity for art to be used in its fullest sense. In art education the final product is subordinated to the creative process. It is the child's process - his thinking, his feelings, his perceiving, in fact, his reactions to his environment - that is important. (pp. 21-33)

In looking at characteristics of growth in children, Lowenfeld looks at these particular complement areas: emotions, intellect, physiology, perception, socialization, aesthetics and creativity. This is evidence of Lowenfeld's considerations for aesthetics and the social and behavioral sciences.

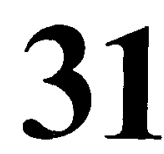


It is the Gestalist views which are immediately evident when looking for a psychological base in Creative and Mental Growth. As in McFee's book, we find here in Lowenfeld's quoting circle, work by Jerome Bruner, Jacob Getzels and H.A. Witkin. Rudolph Arnheim's work in cognition and perception is cited of ten by Lowenfeld, but completely absent in McFee's book. A review of Arnheim's new book, The Power of the Center: A Study of Composition in the Visual Arts, published in 1982, appeared in the Spring, 1983, volume of Studies in Art Education. The reviewer, David A. Pariser, had this to say about Arnheim:

Arnheim's notions about art are informed by his humanism, his formidable grounding in Gestalt theories of perception, and his thorough art historical knowledge. (p. 210)

With this book, Arnheim pursues and enlarges the investigations of Gestalt pioneers like Kohler (1961). He thereby performs a twofold service for those interested in the arts. Firstly, he awakens us from the visual narcolepsy into which we have been plunged by our image-inundated culture. ... Secondly, because of its very broad scope, his work orients us to generative questions concerning the arts. ... Arnheim's theoretical insights have already provided the basis for current research in the psychology of art. The work of Gardner (1973, 1980), Golomb (1974), Olson (1974), to name only three researchers. . . owes much to Arnheim's theoretical ground work. (pp. 212-213)

Besides providing a testimonial to Rudolph Arnheim, the psychologist, Pariser has given recognition to the contributions of Gestalt psychology to art education, as well as indicating how Gestalt ideas are contributing to the field of art education currently.

I find in Lowenfeld's quoting circle, names of art historians, art critics and aestheticians who have strong philosophical backgrounds, such as Clive Bell, John Dewey and Herbert Read.

It is from this philosophical base that I move to the third book which serves as an example in examining art education theory, Art As Experience, by John Dewey (1934).

Looking at the questions surrounding aesthetics, Dewey affronts the issues from a philosophic stance. His chapter titles tell much about his areas of concentration and concern: Chapter III, "Having an Experience," (pp. 35-57); Chapter IV, "The Act of Expression," (pp. 58-81); Chapter XI, "The Human Contribution," 9pp. 245-271); Chapter XIII, "Criticism and Perception," (pp. 298-325); Chapter XIV, "Art and Civilization," (pp. 326350). As can be seen by the selected chapter titles, John Dewey has philosophically considered the domains which are now considered to be aesthetics and the social and behavioral sciences.

From examining the quoting circles of the three books named above, noting in particular the references which come from allied theory domains, a marked trend comes to light. This trend represents a shift in the influences which contribute to art education, from philosophical foundations for aesthetic

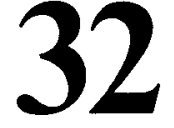


theory to behavioral foundations for aesthetic theory. Figure I serves to illustrate this trend. The shift of emphasis in quoting circle usage, and the span of years between titles and their publication dates, are indicators of a trend taking place in art education.

Figure I Trend of Allied Theory Influence

\begin{tabular}{|c|c|c|c|}
\hline publication & 1934 & 1947 & 1961 \\
\hline title & $\begin{array}{l}\text { Art As } \\
\text { Experience }\end{array}$ & $\begin{array}{l}\text { Creative and } \\
\text { Mental Growth }\end{array}$ & $\begin{array}{l}\text { Preparation } \\
\text { for A.rt }\end{array}$ \\
\hline $\begin{array}{l}\text { quoting circle } \\
\text { is from } \\
\text { primarily }\end{array}$ & $\begin{array}{l}\text { philosophy } \\
\text { aesthetics }\end{array}$ & $\begin{array}{l}\text { philosophy } \\
\text { psychology } \\
\text { aesthetics }\end{array}$ & $\begin{array}{l}\text { psychology } \\
\text { aesthetics }\end{array}$ \\
\hline span of years & \multicolumn{3}{|c|}{13 years } \\
\hline
\end{tabular}

This trend, by indicating a shift in the influences which contribute to art education, also indicates a need to study and to consider this carefully and in depth.

Art education has a tradition of looking to other disciplines for research and rationale, i.e., largely the social and behavioral sciences. The fields of art education, philosophy and aesthetics have grown at the same time. The literature generated from within the field of art education has been, and remains to be, primarily intended for art educators. It is evident that contributions to art education are able to cross the borders between disciplines and to contribute in allied fields.

\section{REFERENCES}

Dewey, J. Art as experience. New York: Minton Press. 1934.

Lowenfeld, V. and Brittain, W. Creative and mental growth. New York: The Macmillan Company. 1970.

McFee, J. Preparation for art. Belmont, California: Wadsworth Publishing Company, Inc. 1970.

Pariser, D. Research and issues: Recent publications Studies in art education. 24(3), 1983. 